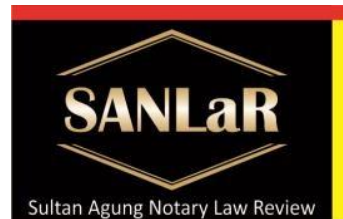

Sultan Aqung

Notary Law Review

ISSN 2686-4428

published by

Master of Notarial Law

Faculty of Law

Universitas Islam Sultan Agung
Semarang

Volume 2 Issue 4, December 2020

Land Registration Problems Related...(Dini Wulansari)

\title{
Land Registration Problems Related to Installation \& Maintenance of Land Boundary Signs
}

\author{
Dini Wulansari ${ }^{*}$, Achmad Sulchan ${ }^{* *}$ and Ngadino ${ }^{* * *}$ \\ *) Student Master of Notary Law, Faculty of Law, Universitas Islam Sultan Agung \\ Semarang, Indonesia, E-mail: diniwulans95@gmail.com \\ $\left.{ }^{* *}\right)$ Lecturer Master of Notary Law, Faculty of Law, Universitas Islam Sultan Agung \\ Semarang, Indonesia \\ $\left.{ }^{* * *}\right)$ Lecturer Master of Notary Law, Faculty of Law, Universitas Islam Sultan Agung \\ Semarang, Indonesia
}

\begin{abstract}
The implementation of land registration activities itself is a government obligation which aims to provide legal certainty in order to protect the rights of land owners which also functions to determine the status of land parcels, who owns it, types of rights, land area, and use and utilization of the land as mandated by the Law. invite. In this research, the objective of this research is to find out what are the problems in land registration, the causative factors, and the role of BPN in dealing with the problems that occur. The approach method used in this research is the sociological juridical approach. This approach is taken to understand law in the context of its society, namely a non-doctrinal approach. The data needed, namely the types of primary data and types of secondary data, were taken by observation, interview and documentation methods. Methods of data analysis using qualitative descriptive analysis, meaning that this research uses data collection methods obtained directly from sources, either in writing or orally. The results showed that there are still land rights holders who do not fulfill their obligation to put up land boundary signs and the factors that cause land rights holders do not fulfill their obligations are due to lack of legal awareness. The role of BPN itself is to disseminate information to the community to install and maintain land boundary signs for the common interest and for the smoothness of the land registration process.
\end{abstract}

Keywords: Problematic; Installation and Maintenance of Boundary Signs; Land Registration.

\section{Introduction}

For humans, land has a very important function and position in life. The increasing number and increasing demand for land as a result of development causes the land to become narrower. Considering the importance of land for human life, it is only natural that regulations regarding land are regulated in such a way so as to minimize the emergence of problems in the land sector. One of the important things to create an 
order in the land sector is the existence of legal certainty in the land sector, especially regarding ownership of land rights by individuals/individuals. ${ }^{1}$

The implementation of land registration activities itself is a government obligation which aims to provide legal certainty in order to protect the rights of land owners which also functions to determine the status of land parcels, who owns it, types of rights, land area, and use and use of the land as mandated in the article. 19 Law Number 5 of 1960 concerning Basic Agrarian Law (UUPA). From these provisions, it can be seen that the objectives of land registration include:

1. to provide legal certainty and legal protection to holders of land rights and other registered rights so that they can easily and be able to prove themselves as holders of the rights concerned;

2. to provide information to interested parties, including the community, so that they can easily obtain the data needed to carry out legal actions regarding registered land parcels;

3. for the implementation of an orderly land administration in which every plot of land including transfer, assignment and abolition of land rights must be registered.

If the above objectives are achieved, it is hoped that legal certainty will be guaranteed. The granting of rights to land is the authority of the state which is carried out by the government, in this case BPN RI, with the procedure specified in the legislation. ${ }^{2}$ With the legal certainty of land registration activities, which is proof of their land rights. proof of land rights is called a certificate. A certificate is the result of land registration activities which are the realization of the objectives of the Basic Agrarian Law, where "land registration activities will produce proof of land rights called a certificate". ${ }^{3} \mathrm{~A}$ land certificate consists of two parts, namely a land book and a measuring letter which are arranged into one inseparable unit. The land book itself is a document containing juridical data and physical data on an object of land registration for which there is already a title. Meanwhile, a Measure Letter is a document containing physical data of a land parcel in the form of a plot map and a description of the physical data of the land, which consists of the area, showing the location of the land parcels, whether in a village/sub-district, sub-district or province, map sheet number, boundary instructions, and the name of the officer measure who measures the plot of land. The basis for the issuance of a Measurement Letter is a Measure Figure, which is a document containing the results of physical data collection/measurement of land parcels of one or more land parcels and the surrounding situation consisting of the first page: registration number of Measure Figure, registration map number, aerial photo number, field location data land, identity data and signature of the applicant, and signature of the measuring officer, the day and date of the measurement, name and signature of the boundary

\footnotetext{
${ }^{1}$ Unnes Law Journal, "Penerapan Asas Kontradiktur Delimitasi dalam Pendaftaran Tanah Sporadik Di Kecamatan Bodeh Kabupaten Pemalang". (2012).p. 56.

2 Dita Raditya Lukita, Skripsi:"Peranan BPN dan Masyarakat dalam Penetapan Batas dan Pemasangan Tanda Batas dalam Rangka Pensertifikatan tanah di Kantor Pertanahan Kabupaten Kendal" (Semarang: Universitas Katolik Soegijapranata Semarang. (2008). p. 1.

${ }^{3}$ Maria SW. Sumardjono, Kebijakan Pertanahan Antara Regulasi dan Implementasi, (Jakarta: Buku Kompas. (2001). p. 81.
} 
ISSN : 2686-4428

mark approval of the owner of the neighboring land. Second page: field data, namely measuring numbers in the form of distances, angles, azimuth or major angles, coordinates and determination of boundaries with a definite scale. Third page: Minutes/Work Report that outlines the legal basis for the implementation of measurement (date and number of assignment letter), Making the Measure Drawing begins with the measurement of the area of land being requested and must comply with cadastral and juridical technical principles in which the methods and procedures for obtaining measuring data on land parcels meet the principle of contract delimitation and the principle of publicity. In order to achieve this, it is hoped that the procedure for measuring and mapping land parcels for cadastral purposes can be standardized, so that from the preparation stage to the implementation of the measurement along with the mapping of the measured data can be accounted for. The measurement process begins with the installation of boundary marks, in this case the plot of land to be measured, is determined in advance the location, boundaries and determination of boundary marks. In determining the boundaries of land parcels, the installation of boundary marks is based on the agreement of the parties concerned, with the designation of the boundaries by the right holder concerned and approved by the holders of the bordering land rights, and the terms of the agreement are set forth in an official report signed by the party giving the approval, The boundary mark can be in the form of a concrete fence, wall fence or any object that is permanent in nature. This aims to minimize land disputes. ${ }^{4}$ In terms of land registration, we can understand that the initial thing that needs to be realized and must be implemented is to put up a land boundary mark/stake. Every individual/individual who owns a plot of land when he wants to register his land for legal certainty of his ownership status needs to understand the importance of putting up the land boundary mark/stake. In Tegal Regency itself, there are still people who do not care about the importance of installing a land boundary mark on a plot of land they own. this happened to a resident of Gumalar Village, Tegal Regency, who submitted an application for land registration at the Tegal Regency Land Office with registration file number: 127129/2018 with the applicant's name: Irmawati. When after the measuring officer schedules the measurement day, When the measuring officer arrives at the location of the land concerned, there is not a single boundary mark/stake attached to his land. So that the measuring officer cannot carry out his work and as a result the land measurement process fails and the applicant is urged to immediately put up a boundary mark/stake, but until now the application for land registration has not been carried out because the measurement has not been installed on the land, thus hampering the land registration process.

\section{Research Methods}

The approach method used in this research is the sociological juridical approach. This approach is taken to understand law in the context of its society, namely a non-doctrinal approach. Through this approach, the legal object will be interpreted as part of the

\footnotetext{
${ }^{4}$ www.eprints@undip.ac.id, Makalah, “Penyelesaian Tanah Non Litigasi di Kab. Konawe Sulawesi Tenggara", Universitas Diponegoro.
} 
social subsystem among other social subsystems. ${ }^{5}$ The specification of this research is descriptive analysis, namely research that describes or describes the applicable laws relating to theories of legal science and a certain condition or object factually and accurately which then analyzes the data obtained from the research. To obtain the necessary data, researchers used several methods as follows: documentation, interviews, and literature study. As well as data analysis using qualitative descriptive analysis, meaning that this study uses data collection methods obtained directly from sources, both written and oral. Sources of data were obtained from interviews with respondents, in this case the Measuring Officer of the Land Office of Tegal Regency, as the executor of the measurement of the land object, regarding the problems that often occur in land registration related to the installation and maintenance of land boundary marks in Tegal Regency, This includes the factors that cause problems in land registration and the role of the Land Office/National Land Agency in addressing the problems in land registration. Another resource person is the Tegal Regency community as the land applicant/owner who makes an application for land registration at the Tegal Regency Land Office.

\section{Results and Discussion}

\subsection{Problems in land registration related to the installation and maintenance of land boundary marks at the Tegal Regency Land Office}

This low interest in community participation can be seen when officers from the land office came to the location, but what was found was when the officers knocked on the residents' doors to conduct socialization, and were told that the land would be measured, the people were busy. Before measuring a land parcel, the boundary of the land parcel is determined. To obtain physical data, the land parcels to be mapped are measured, after their location has been determined, the boundaries are and according to the need, boundary marks are placed in each corner of the land parcels concerned. This is regulated in Article 17 paragraph (1) Government Regulation Number 24 of 1997 concerning Land Registration. In paragraph (2), regarding the determination of the boundaries of land parcels in systematic land registration and sporadic land registration, efforts are made to delineate boundaries based on the agreement of the interested parties. In this case, this means that the knowledge and approval of the neighbors who border the land concerned is needed to be measured. Boundary mark placement. In implementing the boundary measurement of a land parcel, according to Article 18 of Government Regulation Number 24 of 1997 concerning Land Registration, it is approved by the holders of land rights that have borders. This can be seen from the content contained in Article 18, the determination of the boundaries of land parcels that are already owned with a right that has not been registered or that has been registered but there is no measurement letter or picture of the situation or the existing measuring letter or situation picture is no longer in accordance with the actual situation, is carried out by the Adjudication Committee in sporadic land registration, based on the designation of boundaries by the holders of the land rights concerned

5 Widhi Handoko, Contoh Penulisan Proses Penelitian Dalam Metode Penelitian, http://widhihandoko.com/?tag=metode-penelitian-kualitatif, accessed on 17 June 2020 at 18.50 WIB. 
ISSN : 2686-4428

and as far as possible is approved by the holders of the bordering land rights. The obligation to install and maintain boundary markers is intended to avoid disputes or disputes over land boundaries with owners of land parcels that border borders in the future. The determination of the boundaries is carried out by land owners and land owners who are bordering on a Contardicture or what is commonly referred to as the Delimitation Contardicture principle. This contradictory principle can be proven by signing a statement letter by land owners and land owners who border from the north, east, south, west and by the Village Head. If efforts have been made to bring or the parties whose land is directly adjacent to the land to be measured, but the person concerned is unable to attend, in Article 19 of Government Regulation Number 24 of 1997 concerning Land Registration, it is stipulated that the measurement of the land parcels is undertaken temporarily based on boundaries, which in reality are the boundaries of the land parcels concerned. ${ }^{6}$ Land that has not been certified does not have a land boundary, so the presence of land owners is needed. The measuring officer will measure the land according to the instructions of the land owner and the parties whose land borders each other. Prior to the measurement and demarcation activities, the owner and adjacent parties will sign a statement letter regarding the land boundaries previously determined by mutual agreement. This boundary determination is related to the principle of delimitation contradiction which has actually been regulated in Article 17 paragraph (1) of PP 24 of 1997 which states that "To obtain the physical data required for land registration, the land parcels to be mapped are measured, after their location is determined, boundaries and according to the need, boundary marks are placed in every corner of the land parcel concerned."

The determination of the boundaries is an agreement by the land owner and the parties that border. The principle of delimitation contradiction is the principle used as the initial stage of land measurement work carried out by land owners and adjacent land owners. If there is a party who disagrees with the determination of the boundary, a temporary boundary determination will be carried out as regulated in Article 19 PP 24 of 1997. Apart from the absence of the land owner, this principle cannot work properly because the land rights holders do not maintain the land boundaries properly and the existence of land boundary disputes, family disputes or neighbors and land disputes that have already entered the court's domain. ${ }^{7}$

\subsection{The role of BPN in dealing with problems that occur in land registration related to the installation and maintenance of land boundary marks}

In the Regulation of the Head of the Republic of Indonesia Land Agency No. 4 of $2006 \mathrm{JO}$ regulation of the Head of the National Land Agency of the Republic of Indonesia No. 5 of 2006 in part 13, states that the function of BPN in handling land disputes, conflicts and cases (SKP) is to realize land policies for justice and community welfare. BPN has a role in systematically handling and resolving cases, problems, disputes and conflicts throughout Indonesia.

The development target in the land sector is the realization of Land Order Chess which

\footnotetext{
${ }^{6}$ AndiMuttaqin. (2008). PenyelesaianSengketaPertanahan Di Kragilan Kecamatan Kadipiro Oleh Kantor Pertanahan Kota Surakarta. Surakarta : Sebelas Maret University Press. p. 69

${ }^{7}$ Ana Silviana, Teori dan Praktek Pendaftaran Tanah, Semarang : Universitas Diponegoro, Semarang. (2012). p.15.
} 
includes:

1. Orderly Land Law Nowadays there are a lot of control over ownership and use of land by people/legal entities that violate the provisions of the applicable agrarian laws, therefore steps need to be taken:

a. Providing counseling/information to the public regarding Orderly Land Law in order to achieve Legal Certainty which includes controlling control and ownership of land based on the applicable Agrarian Laws. In the sense of orderly implementation of agricultural law, it includes the implementation of orderly documentation and land administration.

b. Regarding legal sanctions for violations that occur

c. Completing laws and regulations in agriculture

d. Improve internal supervision in the field of implementation of organizational duties.

e. Take firm action against individuals who deliberately commit fraud.

2. Orderly Land Administration Today, there are still complaints from the public regarding matters of dealing with land officials, particularly in terms of:

a. Land affairs services are still convoluted and relatively expensive.

b. There are still additional levies

Thus, what is called an Orderly Land Administration is a situation where:

a. For each sector, aspects of physical size, control over use, types of rights and legal certainty are available which are managed in a complete Land Information system.

b. There is a procedural mechanism, simple, fast and mass land service work procedures but ensures legal certainty which is carried out in an orderly and consistent manner.

c. Storage of documents relating to the granting of rights and land use is carried out in an orderly, regular manner and with guaranteed safety.

3. Orderly Use of Land Until now, there are still many lands that have not been exploited/used in accordance with their capabilities and allotments, so that they conflict with the social function of the land itself. Thus, what is called Orderly Land Use is a situation where:

a. The land has been used sustainably, in harmony and balance. In accordance with the potential for various life activities and expectations needed to support the realization of the National Goals.

b. The use of land in urban areas can create a safe, orderly, smooth and healthy atmosphere.

c. There is no formation of interests between sectors in land designation.

d. Orderly Maintenance of Land and the Environment or have very narrow land. The National Land Agency is tasked with managing and developing land administration which includes Regulation of Use, Control, Ownership and Management of Land (P4T), control of land rights, measurement and registration of land and others related to land issues.

\section{Closing}

Land that has not been certified does not have a land boundary, so the presence of land 
owners is needed. The measuring officer will measure the land according to the instructions of the land owner and the parties whose land borders each other. Prior to the measurement and demarcation activities, the owner and adjacent parties will sign a statement letter regarding the land boundaries previously determined by mutual agreement. Based on BPN Head Regulation No. 3 of 2011 concerning Management of Assessment and Handling of Land Cases. The role of BPN in resolving land dispute cases is:

a. The Tegal Regency National Land Agency is obliged to carry out court decisions regarding the resolution of land disputes and conflicts that have obtained permanent legal force.

b. Resolving land disputes and conflicts outside the court in the form of cancellation of land rights, recording them in land certificates/books, issuing land administration letters/decisions.

c. The Tegal Regency National Land Agency stipulates several criteria for resolved land cases as stated in Article 72 of the Regulation of the Head of BPN RI Number 3 of 2011.

\section{References}

Journals:

Unnes Law Journal, "Penerapan Asas Kontradiktur Delimitasi dalam Pendaftaran Tanah Sporadik Di Kecamatan Bodeh Kabupaten Pemalang". (2012).

Books:

[1] Dita Raditya Lukita, Skripsi:"Peranan BPN dan Masyarakat dalam Penetapan Batas dan Pemasangan Tanda Batas dalam Rangka Pensertifikatan tanah di Kantor Pertanahan Kabupaten Kendal" (Semarang: Universitas Katolik Soegijapranata Semarang. (2008).

[2] Maria SW. Sumardjono, Kebijakan Pertanahan Antara Regulasi dan Implementasi, (Jakarta: Buku Kompas. (2001).

[3]AndiMuttaqin. (2008). PenyelesaianSengketaPertanahan Di Kragilan Kecamatan Kadipiro Oleh Kantor Pertanahan Kota Surakarta. Surakarta : Sebelas Maret University Press.

[4]Ana Silviana, Teori dan Praktek Pendaftaran Tanah, Semarang : Universitas Diponegoro, Semarang. (2012).

Internet:

[1] www.eprints@undip.ac.id, Makalah, “Penyelesaian Tanah Non Litigasi di Kab. Konawe Sulawesi Tenggara", Universitas Diponegoro.

[2] Widhi Handoko, Contoh Penulisan Proses Penelitian Dalam Metode Penelitian http://widhihandoko.com/?tag=metode-penelitian-kualitatif, accessed on 17 June 2020 at 18.50 WIB. 